At a General Assembly of IUPAB held in Cambridge, Massachusetts, U.S.A. on 3I August 1969 it was agreed that the Special Commission on Molecular Biophysics should be replaced by separate Commissions on Macromolecular Biophysics and on Subcellular Biophysics. The members of the Special Commissions for the period $1969-72$ were elected as follows:

Commission on the Biophysics of Communication and Control Processes

F. W. CAMPBELL (United Kingdom)

E. DEBOER (Netherlands)

S. FOMIN (U.S.S.R.)

A. HUGELIN (France)

D. KENNEDY (U.S.A.)

J. NAGUMO (Japan)

W. REICHARDT (Federal Republic of Germany)

R. W. RODIECK (Australia)

J. SCHOLES (United Kingdom)

W. M. SIEBERT (U.S.A.)

A. J. H. VENDRIK (Netherlands)

c. VON EULER (Sweden)

Commission on Cell and Membrane Biophysics

B. FRANKENHÄUSER (Sweden)

D. A. HAYDON (United Kingdom)

H. E. HUXLEY (United Kingdom)

A. KATCHALSKY (Israel)

M. KAMIYA (Japan)

R. D. KEYNES President (United Kingdom)

P. G. KOSTYUK (U.S.S.R.)

F. MOREL (France)

H. PASSOW (Federal Republic of Germany)

A. ROTHSTEIN Secretary (U.S.A.)

A. K. SOLOMON (U.S.A.)

J. SZENTAGOTHAI (Hungary)

H. H. USSING (Denmark)

R. VILLEGAS (Venezuela)

W. WILBRANDT (Switzerland) 
Commission on Radiation Biophysics
G. W. BARENDSEN (Netherlands)
J. W. BOAG (United Kingdom)
L. R. CALDAS (Brazil)
z. DIENSTBIER (Czechoslovakia)
M. ERRERA (Belgium)
H. GLUBRECHT (Federal Republic of Germany)
A. R. GOPAL-AYENGAR (India)
L. P. KAYUSHIN (U.S.S.R.)
S. KONDO (Japan)
A. M. KUZIN (U.S.S.R.)
B. LARSSON (Sweden)
R. LATARJET (France)
R. B. SETLOW (U.S.A.)
C. A. TOBIAS (U.S.A.)

Corresponding Members

T. ALPER (United Kingdom)

T. BRUSTAD (Norway)

M. BUGNARD (France)

A. BUZZATI-TRAVERSO (Italy)

A. HOLLAENDER (U.S.A.)

B. RAJEWSKY (Federal Republic of Germany)

J. TIGYI (Hungary)

Commission on Macromolecular Biophysics
E. BLOUT (U.S.A.)
F. BUC (France)
J. EDSALL Convener (U.S.A.)
A. EHRENBERG (Sweden)
N. GABELOVA (U.S.S.R.)
W. GRATZER (United Kingdom)
W. HOPPE (Federal Republic of Germany)
A. KLUG (United Kingdom)
S. LIFSON (Israel)
v. LUZZATI (France)
D. C. PHILlIPS (United Kingdom)
G. N. RAMACHANDRAN (India)
H. A. SCHERAGA (U.S.A.)
M. VOLKENSTEIN (U.S.S.R.)
A. WADA (Japan)

Commission on Subcellular Biophysics

T. ANDERSON (U.S.A.)

W. ARBER (Switzerland)

P. BERG (U.S.A.) 
Commission on Subcellular Biophysics (cont.)

F. BONHOEFFER (Federal Republic of Germany)

J. A. v. BUTLER (United Kingdom)

J. P. Changeux (France)

A. ENGSTRÖM (Sweden)

L. ERNSTER (Sweden)

o. MAALøE (Denmark)

A. MONROY (Italy)

M. SELA (Israel)

J. TOMizaWA (Japan)

R. G. TSANEV (Bulgaria)

R. C. WILLIAMS (U.S.A.)

H. WITT (Federal Republic of Germany)

J. WYMAN Convener (U.S.A.)

\section{Committee on Education}

w. FULLER (United Kingdom)

H. HOFFMAN-BERLING (Federal Republic of Germany)

F. HUTCHINSON Chairman (U.S.A.)

A. KATCHALSKY (Israel)

M. KOTANI (Japan)

F. OOSAWA (Japan)

G. N. RAMACHANDRAN (India)

D. SHUGAR (Poland)

F. SNELL (U.S.A.)

R. VILLEgas (Venezuela)

Y. A. VLADIMIROV (U.S.S.R.)

\section{Corresponding Members}

W. ROSENBLITH (U.S.A.)

A. VENDRIK (Netherlands)

\section{STATUTES OF IUPAB}

Paragraphs $6,8,13$ and 14 of the Statutes of IUPAB were amended. The revised Statutes are as follows:

\section{Aims and function of the Union}

r] The objects of the International Union for Pure and Applied Biophysics are:

(a) to organize international co-operation in biophysics and to promote communication between the various branches of Biophysics and allied subjects;

(b) to encourage within each country co-operation between the societies that represent the interests of biophysics;

(c) to contribute to the advancement of biophysics in all its aspects. 
2] For these purposes it shall have power:

(a) to set up commissions or bodies for special purposes;

(b) to organize international meetings and conferences;

(c) to collaborate with other scientific organizations;

(d) to act in all ways as a constituent union of the International Council of Scientific Unions in accordance with the statutes of that body;

$(e)$ to derelop any activity deemed helpful to the forwarding of its declared objects.

\section{Membership}

3] The International Union shall consist of a group of adhering national bodies. In each country the adhering body shall be the National Academy, the National Research Council or similar institution, a scientific Society or a group of such Societies, or a body specially formed for the purpose of adhering to the Union. In each case a National Committee of Biophysics shall be formed, and adherence to the Union shall be ratified when the membership of this Committee has been reported to, and recognized by, the General Assembly of the Union.

4] The term 'country' shall be understood to include all territories which are scientifically independent.

5] The adhering bodies shall be required to pay an annual subscription to the International Union. (See Article IV.9.)

\section{National Committees}

6] Each National Committee will be expected to co-ordinate within its own country the interests of the various branches of biophysics.

Each National Committee shall appoint delegates to represent it at the General Assembly of the Union, and shall select a leader of its delegation, who shall vote on behalf of his country at the General Assembly. (See Article IV.10.)

\section{General Assembly}

7] The work of the Union shall be directed by the General Assembly of delegates, which shall normally meet once every three years.

8] The membership of the General Assembly of the Union shall consist of delegates appointed by the national adhering bodies, the delegates of the Special and Affiliated Commissions (see paragraph 9 and Article VII), the officers, and the ordinary members of the Council. Only the delegates, present in person, may vote.

9] There shall be three levels of annual subscription, the amount to be fixed by the General Assembly. Depending upon the level of subscription chosen by the country, it shall have the right to send one, two or three delegates to 
the General Assembly. In addition, each Commission has the right to send one delegate to the General Assembly.

10] At the General Assemblies, questions of an essentially scientific nature shall be decided by a simple majority of all delegates present. Questions of an essentially administrative nature shall be decided by a simple majority vote of countries (each country having one vote) except for the modification of Statutes. (See paragraph 22.) The President shall decide whether a question is of an essentially scientific or essentially administrative nature.

\section{$V$. Officers of the Union}

II] The Officers of the Union shall be a President, a Vice-President, and a Secretary-General, elected by the General Assembly, together with an Honorary Vice-President. The President shall hold office for a period of about three years, i.e. from the end of one General Assembly to the end of the succeeding General Assembly. Similarly, the Vice-President may hold office for about three years, normally then becoming President. The immediate past President shall hold office for three years as the Honorary Vice-President. The Secretary General shall hold office for six years, but may be re-elected for further periods of three years to a maximum of twelve years.

12] The Office of the Secretary-General shall be the official centre of the Union. It shall be the duty of the Secretary-General to maintain relationship with all bodies adhering to the International Union and all other relevant organizations within the field of biophysics. He shall prepare budgets and agenda, and circulate them at least four months before meetings of the Council and General Assembly.

\section{The Council}

13] The executive body of the General Assembly shall be a Council, which shall be guided in all its decisions by the tradition of free international scientific co-operation. The officers of the Union, acting as a group, may conduct the business of the Council in the intervals between meetings of the Council, reporting subsequently to the Council.

14] The Council shall consist of the four officers of the Union, who shall also be the officers of the Council, and not more than 12 ordinary members who shall be elected from among the members of the General Assembly. The Council should, as far as possible, be representatives of all aspects of pure and applied biophysics.

The ordinary members of the Council shall serve for a term of three years and may not serve for more than two consecutive terms. The Council may co-opt to any vacancies which occur (including the officers) and any person so co-opted has the same tenure of office as the person he replaces. 
No member of the Council, either an ordinary member or an officer, shall be individually liable for the corporate debts and liabilities of the Union or any of its Commissions or Committees.

15] The meetings of the Council shall be held:

(a) during the General Assembly;

(b) normally once a year between each General Assembly, but exceptionally at other times upon the decision of the Council.

Seven members of the Council shall constitute a quorum at a Council meeting.

\section{Commissions}

r6] Special Commissions may be set up by the General Assembly or by the Council (subject to confirmation by the next General Assembly) to take responsibility:

(a) for the various branches of biophysics;

(b) for any other necessary purpose, including co-operation with other international organizations.

17] The General Assembly shall elect the full members of each Special Commission, taking into account the recommendations of the Council. The Special Commissions shall elect their own President and Secretary and may co-opt corresponding members with the approval of the Council.

18] Existing international bodies may be admitted as Affiliated Commissions to the Union by the General Assembly or by the Council (subject to confirmation by the next General Assembly). Affiliated Commissions shall pay an annual subscription, the amount to be designated by the General Assembly.

19] The constitution and statutes of all Commissions must be approved by the Council. The Secretary of each Commission shall be responsible for the presentation of a report on the work of his Commission at each General Assembly.

In Special Commissions, decisions are made on the majority of the full members' votes, not by countries.

20] The Council shall have the right to designate a representative to sit on the executive body of each Affiliated Commission. The Secretary-General shall receive copies of all official communications pertaining to the activities of the Affiliated Commissions.

2I] In addition to grants made to them by the Council, Commissions may receive grants from other sources. 
VIII. Modification of the Statutes

22] The present Statutes may be modified only by a two-thirds written vote of all national bodies present at a General Assembly to which prior notice of the change has been given on the agenda.

23] The English text is to be used in interpreting the present Statutes.

Adopted STOcкHOLM, 2 AUGUST $196 \mathrm{I}$

Modified VIENNA, 7 SEPTEMBER I 966

Modified CAmbridge, MaSS., 3I AUgust 1969 